\title{
Unsustainable charcoal production as a contributing factor to woodland fragmentation in southeast Kenya ${ }^{1}$
}

\author{
EEVA RUUSKA
}

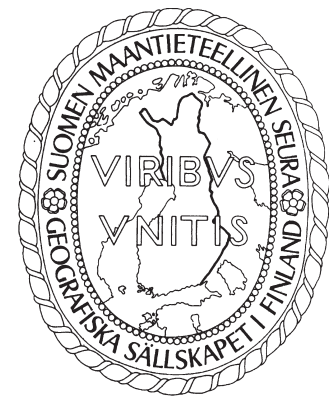

Ruuska, Eeva (2013). Unsustainable charcoal production as a contributing factor to woodland fragmentation in southeast Kenya. Fennia 191: 1, pp. 58-75. ISSN 1798-5617.

Drawing from a holistic research approach, this paper contributes to the studies of land cover change and sustainable development in Kenya, and to the planning of sustainable future in Dakatcha Woodland, SE Kenya. As an unprotected global hotspot for biodiversity, Dakatcha Woodland has suffered from the unsustainable use of forest resources. The relation of charcoal production to land cover change and its socioeconomic impact are studied in detail. A supervised land cover classification formed using four SPOT satellite images from 20052006 and 2011 revealed that the woodland is fragmenting and that the Important Bird Area (IBA) demarcation should be reconsidered. Through in-situ observation, household questionnaires and semi-structured expert interviews, it was found that more than half of the 90 households assessed are involved in charcoal production - a higher figure than peer studies have suggested -, and that, while the charcoal network offers income to many, it bears an negative impact on the environment. It was also discovered that, like in Kenya, in Dakatcha Woodland the demand for woodfuels (charcoal and fuelwood) is one of the key drivers of deforestation and land degradation. As such, woodfuel energy is a cross-cutting issue, tying together forest resources, livelihoods and sustainable development, and thus demands further research. Forest management of Dakatcha Woodland must be planned in accordance with all stakeholders in a sustainable manner, drawing from agroforestry and participatory forest management systems, and keeping environmental factors in mind for the maintenance of ecosystem services.

Keywords: Kenya, charcoal, remote sensing, land cover change, sustainable forest management, sustainable development

Eeva Ruuska, MegaleGroup, Heriberto Frías 1104, Col. Del Valle, C.P. 03100, México D.F., MEXICO. E-mail: eevamaria.ruuska@gmail.com

\section{Introduction}

Land use and land cover change is often driven by population growth and the accompanying economic growth and development, which lead to demands for land to produce food, feed, fibre and fuel (FAO 2010a). In Kenya, the demand for woodfuel is one of the key drivers of deforestation and land degradation. The fuelwood accounts for $70 \%$ of all energy consumed nation-wide and up to $90 \%$ of that consumed in rural areas (Diaz-Chavez et al. 2010). Woodfuels are used because they are the most available and affordable energy source in rural are- as (Anderson et al. 1999; FAO 2010b). Woodfuel energy is an issue that ties together forest resources, livelihoods and sustainable development. Forests act as a safety net for the poor, providing them with goods and services they are unable to afford in the marketplace. The loss of forests and denied access to forest products deprives rural dwellers of the forest goods and services they need for their subsistence and livelihoods. The cost of forest goods tends to rise as forests become scarcer, with obvious implications for the poor in towns where people need to use the larger portion of their income to buy fuelwood, and for women in the countryside who use 
more time to collect it from further away. The loss of forests can also harm tourism and food sources leading to increasing hardship for the poor (CIFOR 2005).

Women and girls are generally the most involved in the collection and use of woodfuels for cooking, which signifies that women largely determine household energy consumption patterns (Amous 1999). Woodfuels also bare an impact on their health because of the heavy carrying loads and smoky cooking environments (Anderson et al. 1999; FAO 2010b). On the other hand, a large number of people are employed in different phases of woodfuel production. The charcoal supply chain employs through the collection and sizing of the wood, the preparation of kilns for converting wood to charcoal, the loading of wood into kilns and the unloading of charcoal after conversion, in addition to bundling, packaging, transportation and marketing. Additional employment is created by the activities that use charcoal, such as restaurants and food processing industries (FAO 2010b).

According to Chambers and Conway (1991), sustainable development suggests that environmental sustainability and human economic development are compatible, attainable and inseparable, enabling a situation where both development and environmental protection are achievable. Livelihood, for one, is sustainable when it is able to cope with and recover from stresses and shocks, and maintain or enhance its capabilities and assets both now and in the future, respecting the natural resource base. Currently, unsustainable resource use is threatening the ecosystem services on which our lives depend. The possibility of future generations to meet their needs should, however, be as important as our own needs, as was first stated by the Brundtland Commission in 1987 (WCED/UN 1987).

Poverty reduction and maintenance of sustainable livelihood systems in developing countries are related to good land use practices (KNCHR 2006); likewise, clear tenure and user rights are essential for successful forest management (Eliasch 2008). Sustainable land use and development depend on national, regional and local policy and leadership, and on the participation of local people, who must perceive its benefits in order to contribute positively to the settings (Skidmore 2002). Without secure land tenure and user rights, locals are reluctant to participate in the sustainable management of the forests and to safeguard the forest ecosystem services (White \& Mustalahti 2005; FAO 2006). The Kenyan government policy states that all forests should be managed on the basis of approved management plans guided by sound forest management principles (Mbuvi et al. 2011).

According to Nature Kenya (2008), the study area of Dakatcha Woodland in SE Kenya has suffered major damage from uncontrolled logging and clearing especially - within the Cynometra-BrachylaenaBrachystegia forests - to provide firewood for local energy needs charcoal burning to satisfy energy demands in the nearby centres and towns - mainly Malindi and Mombasa -, encroachment by local people into the woodland through agricultural expansion and shifting cultivation, fires from charcoal burning and agricultural activities, and extremely high levels of unsustainable bush meat hunting. Nearly $40 \%$ of the households in Dakatcha Woodland are involved in charcoal production (Nature Kenya 2010). Weak institutional framework and land tenure system, deforestation and poor soils, high population growth and illiteracy and ignorance are some of the contributing factors to the poverty experienced in the area (Mbuvi et al. 2011). Although the area lacks a Management plan, zonation of the woodland was proposed in a master plan drafted in 2010 in a participatory way in order to facilitate the development of conservation practices that would sustain livelihoods (ibid.).

Remote Sensing (RS) and Geographical Information Systems (GIS) provide a means to quantitatively assess the change in land cover and thus the state of the environment. Combined with qualitative and quantitative socio-economic data collected with semi-structured interviews, observation and questionnaires offer ways to assess the poverty-environment linkages and data for land and forest resource management planning.

This paper has a deductive approach as it leans on the biodiversity and ecosystem service theory formed by the Millennium Ecosystem Assessment (MA 2005), implying that diminishing biodiversity and weakening ecosystem services deteriorate livelihoods. The first objective is to map the recent change in land cover by analysing in-situ data and satellite imagery from four SPOT satellite images from 2005, 2006 and 2011 in RS and GIS applications. The second objective is to find out the significance charcoal production has for local livelihoods and the influence it bears, along with the local energy consumption, for the environment. The third objective is to explore the possibilities for sustainable development and livelihoods in the area. 


\section{Study area}

Dakatcha Woodland is an unprotected tract of community held land (Trust land) and private land on $03^{\circ} 01^{\prime} \mathrm{S}, 39^{\circ} 51^{\prime} \mathrm{E}$ in the Magarini District, Coast Province, SE Kenya (Fig. 1). It is one of the last patches of relatively intact coastal woodland that, together with Arabuko-Sokoke Forest (ASF) and fragments of Madunguni forests form the only remaining part of the northernmost block of Miombo woodlands, which used to extend from southern Somalia to northern Mozambique (Musila et al. 2006; Mbuvi et al. 2011).

Dakatcha Woodland was identified as an Important Bird Area (IBA) in the 1990s. The IBA area reaches 25,000 ha to the northwest of Baricho town and another 7,000 ha to the northwest of Marafa town (Mbuvi et al. 2011). Conservation International recognises Dakatcha Woodland as a Coastal Forests Global Hotspot and as one of the 160 Key Biodiversity Areas (KBA) that are identified in the Eastern Arc Mountains and Coastal Forest of Kenya and Tanzania Biodiversity region (Nature Kenya 2008; Muchiri et al. 2010; Mbuvi et al. 2011). It is the only site outside ASF where the Clarke's Weaver bird (Ploceus golandi) is known to dwell (Nature Kenya 2008).

\section{Physical geography}

The landscape of Dakatcha Woodland is gently undulating; the slope gradient varies between 0 to $10 \%$, and the altitude, between 25 and $350 \mathrm{~m}$ a.s.I. (Foeken 2003). Red soils, brown soils, blackcotton soils and sandy soils are the main soil types (Teel 1988). According to FAO 90 classification (ISRIC 2010), dominant soils in the area are Vertisols, Solonetz, Ferralsols and poorly fertile sandy Arenosols, which provide the base for the Miombo woodlands.

The Inter-Tropical Convergence Zone (ITCZ) defines two rainy seasons in Dakatcha Woodland: the main rainfall happens from April to June, leading into a relatively short water surplus in the soil (Foeken 2003). Dakatcha Woodland IBA is located almost completely in the semi-arid Agro-Climatic Zone $\mathrm{V}-1$, where the mean annual temperature ranges from $24{ }^{\circ} \mathrm{C}$ to $30{ }^{\circ} \mathrm{C}$, moisture availability from $25 \%$ to $40 \%$, average annual rainfall from 450 to $900 \mathrm{~mm}$, and average annual potential evaporation from 1,650 $\mathrm{mm}$ to 2,300 $\mathrm{mm}$ (Braun 1980).

Field observations support Macharia's (1996) four physiognomic vegetation classes in the area: $1)$ the main vegetation type is woodland com-

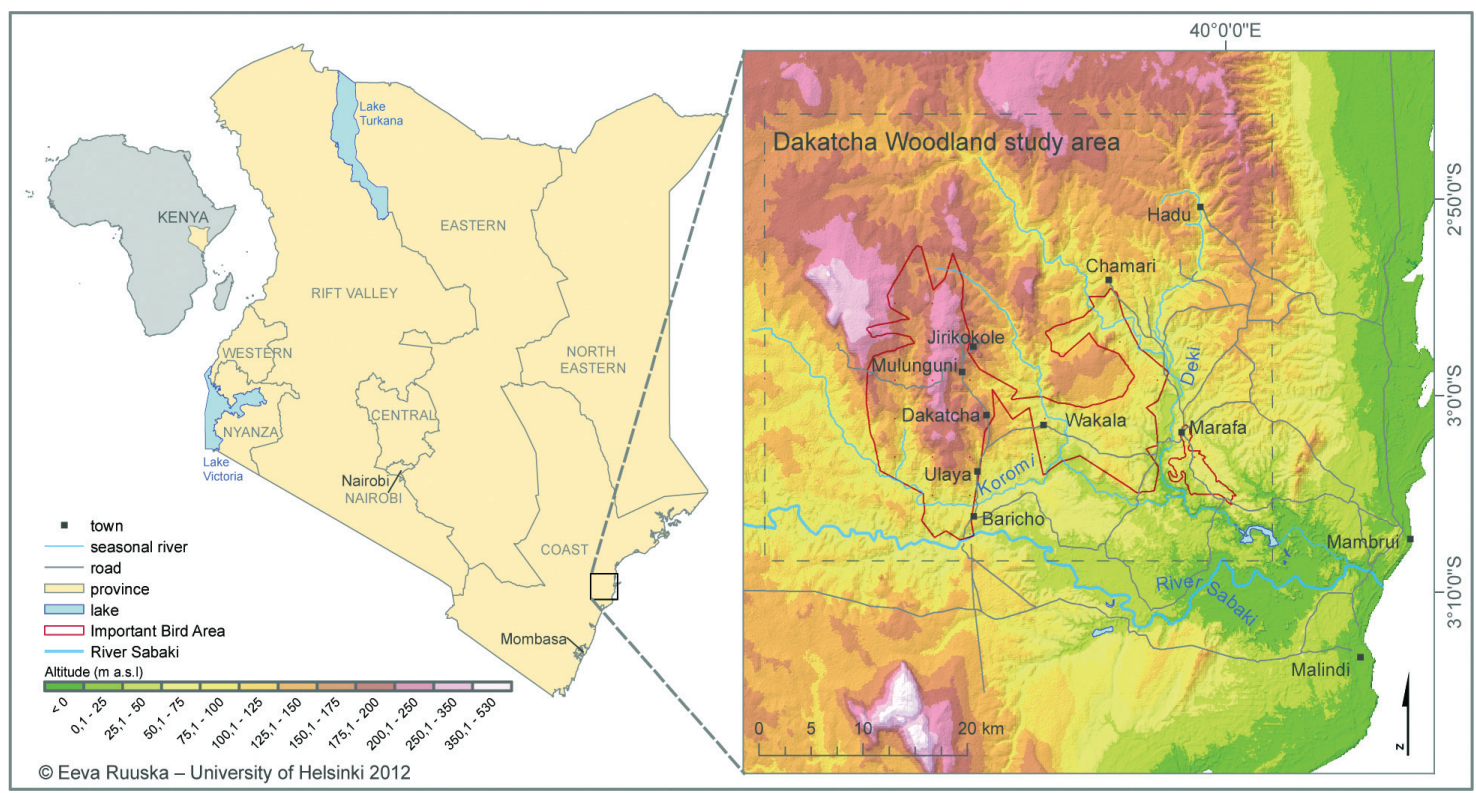

Fig. 1. Location of Dakatcha Woodland and Important Bird Area (IBA) in SE Kenya. Magarini District borders Malindi District and River Sabaki to the south, Tana River District to the northwest, and it is located 25 to $50 \mathrm{~km}$ inland from the Indian Ocean. Sources: DEM from Vagen 2010 and shapefiles from ESRI ArcGIS/ A Rocha Kenya. 
posed of broadly spreading Brachystegia spiciformis trees over 5 meters high and sparse ground cover; in areas including large Julbernardia magnisipulata and Manilkara sulcata trees, the understorey includes a variety of shrubs; 2) extremely dense broad-leaved thicket mostly less than 5 meters high with completely closed canopy, mainly Cynometra webberi species; 3) areas of scrub, dense thicket or bush land with succulents; and 4) grassy areas with scattered trees and shrub.

\section{Socio-economical features}

The population, 30,000 in 2010, is sparsely distributed with concentrations in major trading centres such as Marafa, Garashi, Baricho and Adu (Marafa Government Office 2011; Mbuvi et al. 2011). Access to housing, sanitation, water and energy directly impacts the welfare of household members (KNBS 2007). In Dakatcha Woodland particularly, the access to water has been limited since, during dry periods, the two seasonal rivers - Deki and Koromi - dry out and leave River Sabaki as the main water source (A Rocha Kenya 2009). The locals mainly use firewood, charcoal and kerosene for energy supply (Kinayia 2011; Marafa Government Office 2011). The government and Malindi County Council (MCC)-administered Rural Electrification Project was ongoing during April 2011 in the area to bring in mainly lighting-purposed electricity to dispensaries and shops. Solar panels are used in some of the villages, but the repairs and maintenance of photovoltaic devices has proved difficult in the area (Marafa Government Office 2011). The locals lack resources, in terms of both money and willingness, to obtain and get used to alternative energy options like the improved cooking stoves jikos (Ngari 2011).

Farming, livestock keeping, small businesses and casual labour are the main economic activities in the area (Marafa Government Office 2011). The main source of income used to be pineapple farming, but recently off-farm work, such as ecotourism or charcoal making, has become a supplier of additional income (Ikiara 2003; Waaijenberg 2003). MCC considers Dakatcha Woodland as a challenging area in terms of available opportunities to support livelihoods, mainly due to the sandy soils that cannot support substantial agriculture (Kinayia 2011). Table 1 describes other contributing factors.
Table 1. Socio-economic data from Dakatcha Woodland reveal low human development indexes in the area.

\begin{tabular}{lc}
\hline Population (2010) & 30,000 \\
Pop. growth rate (2006) & 3.9 \\
Primary enrolment rate (2005) & $+: 67.7 \delta: 84.6$ \\
Secondary enrolment rate (2005) & $+: 1.7 \delta: 14.7$ \\
$\begin{array}{l}\text { Poverty index rank (out of 210 } \\
\text { constituyencies in Kenya in 2005) }\end{array}$ & 189 th \\
Average household income (2010) & 82,516 KES \\
Pop. living in absolute poverty (2002) & $66 \%$
\end{tabular}

Sources: KNCHR 2006, Republic of Kenya 2005, Nature Kenya 2010a

In 2006, the conservation NGO Nature Kenya started to work with the Critical Ecosystem Partnership Fund (CEPF) on the communities adjacent to Dakatcha Woodland to institute sustainable systems such as bee-keeping and eco-tourism. There are excellent opportunities for eco-tourism in the area due to rich biodiversity and cultural attractions like the Kayas sacred forests (Fig. 2). However, poor marketing and infrastructure together with unsustainable use of natural resources set challenges to the development of the sector (Mbuvi et al. 2011).

In Dakatcha Woodland, the locals have formed management groups because the MCC does not know the exact boundaries of the piece of land under its jurisdiction nor does it have a management system in place (Musila et al. 2006; Mbuvi et al. 2011). The lack of clear management and formal protection status quickly exposes the area as being fragmented, disturbed and unsustainably exploited (Musila et al. 2006).

Land cover change analysis by Mwanikah (2008) shows a decline of $19.3 \%$ in the forest cover from 1975 to $1987,-48.4 \%$ (1987 to 2000) and $-58.3 \%$ (1975 to 2000) in the area including Dakatcha Woodland. Glendey found in 2005 a general decline of $40 \%$ in the forest areas surrounding Dakatcha Woodland, amounting to a loss of 710 ha per year over the period 1990 to 2000 (Mbuvi et al. 2011). The forest cover had reduced especially in the SE parts of the area, around Wakala, Magarini, Garashi and Marafa towns. This can be attributed to the increase in urbanization, farming and livelihood activities such as charcoal burning and timber cutting in the area (Mbuvi et 


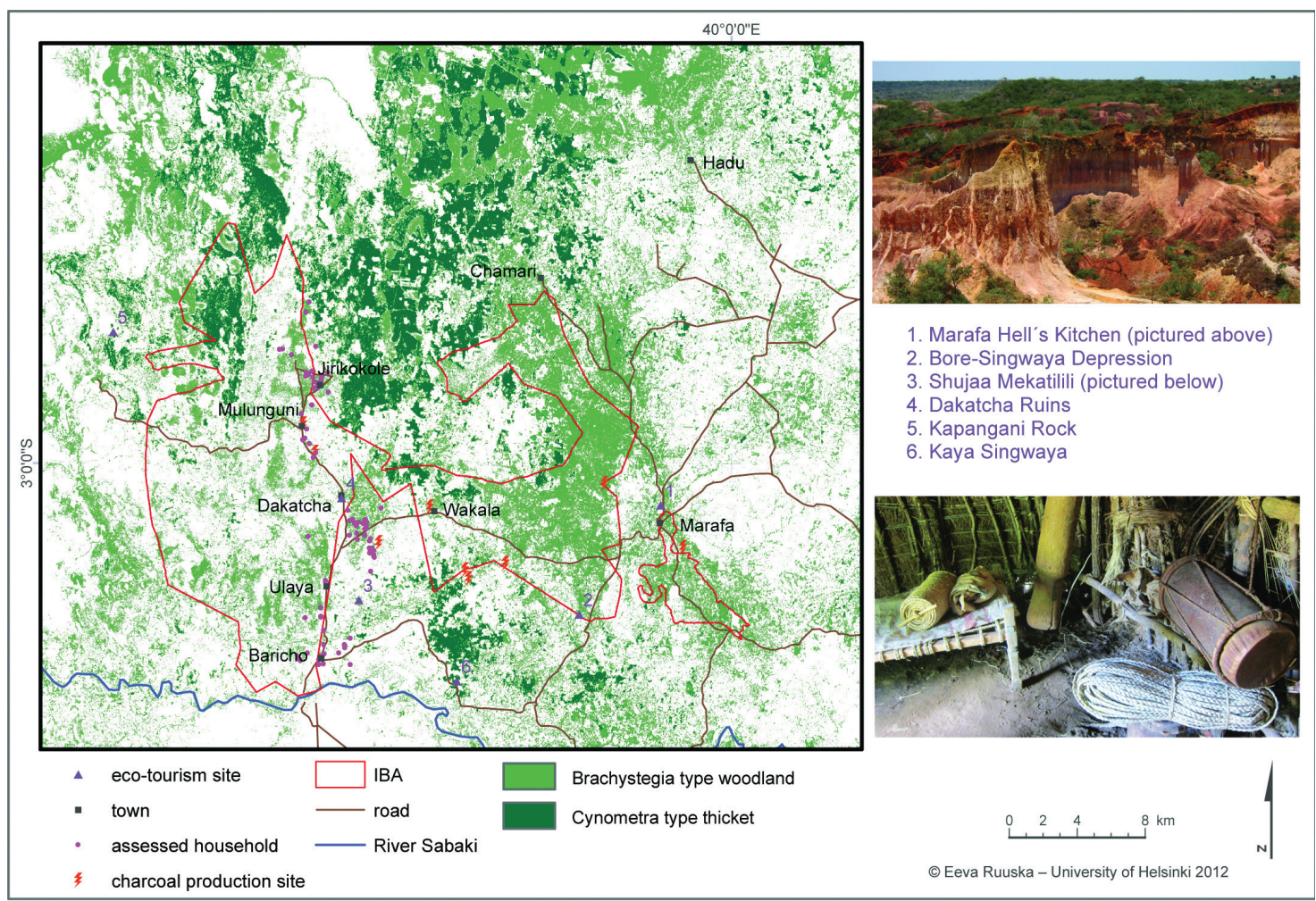

Fig. 2. Main towns, eco-tourism sites and road infrastructure in Dakatcha Woodland. Canyons of Hell's Kitchen located in Marafa serve as one of the main tourist attractions in Malindi district. From the 18,000 tourists passing by just $40 \mathrm{~km}$ away along the Lamu - Malindi Mombasa road yearly, only 1,500 domestic and foreign tourists visit Dakatcha Woodland (Mwambire \& Katana 2010). The figure also depicts the location of assessed households and visited charcoal production sites in the woodlands and thickets as they were in 2011.

al. 2011, Fig. 2). Musila et al. (2006) state that the District Forest Officer (DFO) in Malindi was aware of the destructive activities but no regular patrols had been carried out due to lack of resources.

\section{Data and methods}

\section{Socio-economic data}

Data was collected through observation, questionnaires and interviews. Literature from $\mathrm{Na}$ ture Kenya (2010), Mbuvi et al. (2011) and KNBS (2007) provided important household data while Musila et al. (2006), KNCHR (2006), FAO (2010b), Kinyanjui (1987) and Diaz-Chavez et al. (2010) contributed to information about livelihoods and woodfuels.
Questionnaires including both quantitative and qualitative questions were conducted within 90 households during one week in October 2010 by three local research assistants who worked individually in the western side of Dakatcha Woodland (Fig. 2). One of the questionnaires failed. The size of the sample, as well as the sampling area, restricts broad generalization of the results (Hirsjärvi et al. 2004). Nature Kenya staff was consulted about the questionnaire before starting the household visits to assure its suitability. The use of assistants was chosen due to a time constraint, but also because the local assistants and staff from Nature Kenya opined that an outsider (young white female) would not get reliable data.

Semi-structured expert interviews were agreed on beforehand and the purpose of the interviews 
was clear to the participants ${ }^{2}$. Themes covered the current state of the woodland related to land tenure and management, household energy consumption and charcoal production and transportation in the area, administrative settings in place related to charcoal production, current income-generating activities and the possibilities for sustainable management systems.

Improvised informal discussions and un-structured theme interviews were conducted during the field observations, for instance, if local charcoal makers, local dwellers, policemen, cess collectors and charcoal transporters were met in the forest. A monitoring of the volume of charcoal transport was commissioned in the Sabaki Village, where research assistants counted the amount of charcoal and firewood transported on vehicles daily from 6am to 6pm during one week (April 18 to 24, 2011).

Contents of the interviews and open questions in the questionnaires were analysed by themes and connections that related them to the theoretical framework as recommended by Hirsjärvi and Hurme (2006). Statistical analysis was conducted on Microsoft Excel. Research assistants were compensated for their work, but participating households and interviewees received no compensation.

\section{Remote sensing and GIS data}

RS and GIS data was obtained both by desk studies and in situ measurements and observations. A Digital Elevation Model (DEM) from Africa Soil Information Service - AfrHySRTM (Vagen 2010) was used alongside topographic maps and other shapefiles provided by A Rocha Kenya and Nature Kenya in producing data for the mapping. To derive soil data, KSS and ISRIC-compiled 1:1M geo-referenced Soil and Terrain Database for Kenya (kenSOTER) (ISRIC 2010) was used. Shapefiles of existing accessible roads, water bodies, important towns and ecotourism sites were digitised based on the scanned topographic maps, satellite images and field observations. Tree DBH that is the outside bark diameter at breast height was used to measure the maturity of trees in the randomly chosen 17 test plots of $30 \times 30 \mathrm{~m}$ each. Breast height is defined as $1.37 \mathrm{~m}$ above the forest floor on the uphill side of the tree (FORESTRY 2011). Bila and Lindgren (1998) define a mature Brachystegia spiciformis to be of 0.4 to $0.6 \mathrm{~m}$ on DBH. However, trees $\geq 0.15 \mathrm{~m}$ in $\mathrm{DBH}$ were classified as mature in this study as this size is commonly used for charcoal production in the area. For all spatial data, if needed, the geographic coordinate system was transformed to follow the default parameters of the Kenya Topographical maps (Table 2).

Spatial data related to charcoal production sites and household locations as well as ground truth and ground reference test data for accuracy assessment was collected using Global Positioning System (GPS) device MAGELLAN. ERDAS IMAGINE 9.2 and ENVI software were used for deriving the land cover data whereas ArcGIS 9.3 applications were utilised for map making and analysis.

SPOT (Le Système Pour l'Observation de la Terre) imagery was derived from the EOLISA image server. It was used due to appropriate resolution and access to suitable scenes. Figure 3 presents the four unprocessed scenes from January 5, 2005 (SPOT 2005), January 14, 2006 (SPOT 2006) and January 20, 2011 (SPOT 2011a \& SPOT 2011b), whereas the scene parameters are visible in table 3.

Unsupervised land cover classifications were conducted before the fieldwork, but supervised classification was chosen as the final classification method because it gives the analyst more control due to a priori knowledge about the area of interest (Clark 2007). Spectral statistics for each land cover class were used for a classifica-

Table 2. Coordinate system used in Survey of Kenya 1:50,000 scale series topographic maps and Dakatcha Woodland mapping. A geo-registered mosaic of eight Kenya Topographical 1:50,000 map sheets from 1981 and 1991 (Kenya Topographical Map 1:50,000; sheet mosaic 1981/1991), acquired from Omnimap, was utilised in the satellite image map-to-image rectification and in digitalization of infrastructure and waterways.
Projection

Shperoid

Datum

Scale factor at central meridian

Longitude of central meridian

Longitude of origin of projection

False easting

False northing
Transverse Mercator

Clarke 1880

Arc 1960

0.999600

39:00:00E

$0: 00: 00 N$

$500,000 m$

$10,000,000 m$ 


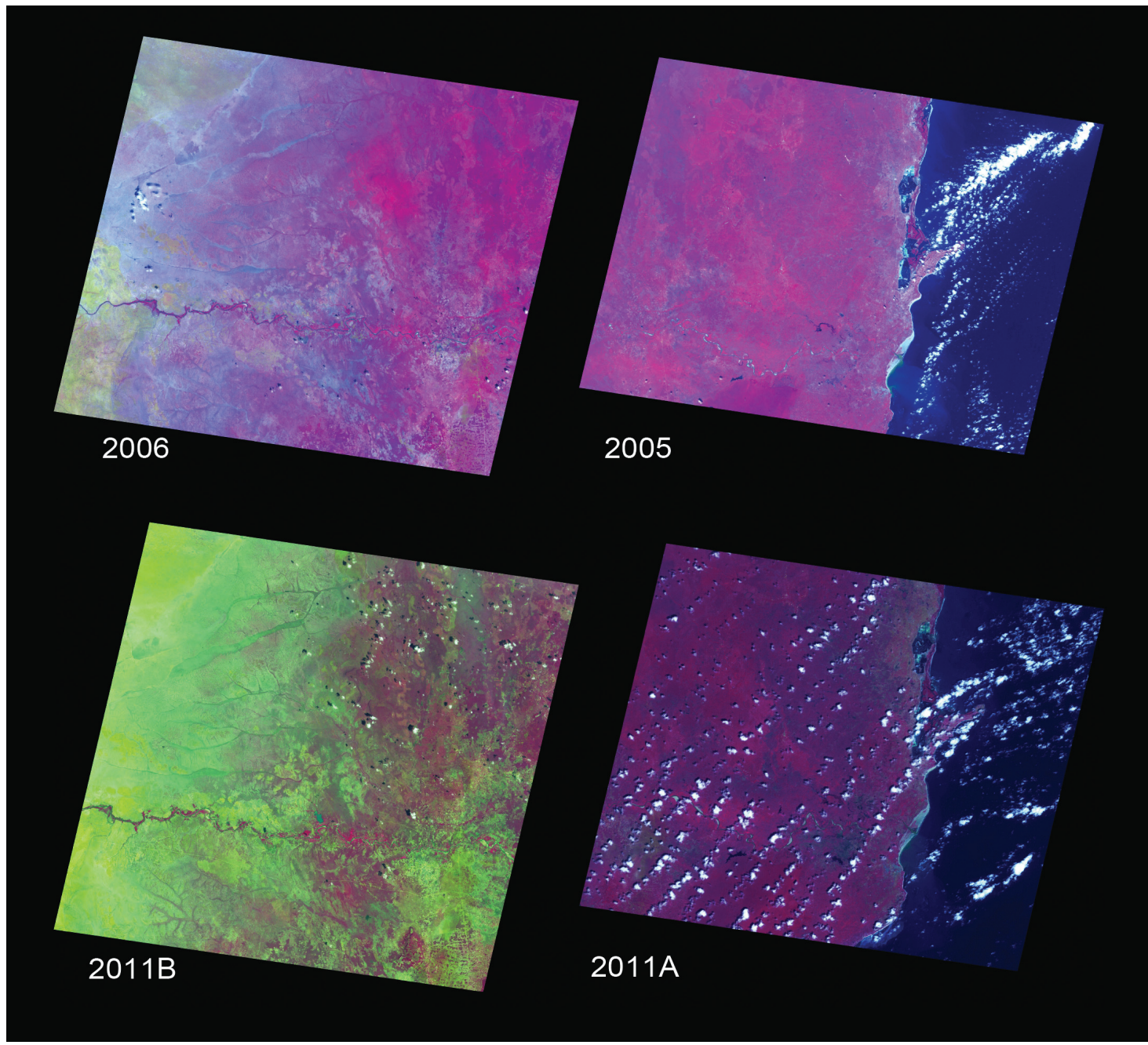

Fig. 3. Unprocessed SPOT scenes used in the analysis.

tion algorithm to assign every pixel in an image to the class for which its multispectral properties are most similar (Woodcock et al. 2002; Clark 2007). Scenes were pre-processed and classified prior to mosaicing in order to minimise the influence of differences in scene reflection in the classification result. The change detection was done by comparing the percentage of each land cover class in classified images from 2005/06 and 2011. Ground reference test data was used for accuracy assessment together with reference data collected from the images. Figure 4 describes the steps taken in pre-processing and classification of the imagery.

Land Cover Classification System (LCCS) was used to create a land cover legend compliant to the FAO - UNEP international standard. The user must have good a priori knowledge of the actual land cover in the area to be classified (Clark 2007). The applied classification scheme depends on the purpose of the land cover classification, in this case, the main mapping object were the remaining forests and woodlands (Table 4). 
Table 3. Scene parameters for the SPOT imagery. Level 2A SPOT data has been orthorectified to a UTM projection with a WGS-84 spheroid and datum. Images were taken during the same season, making the image mosaicing and land cover change detection easier as the objects appear similarly and the seasonal change of vegetation does not confuse the classification. The ground truth data was collected, however, in a different season, which might cause some minor incoherence.

\begin{tabular}{|c|c|c|c|c|}
\hline Scene parameters & SPOT 2005 & SPOT 2006 & SPOT 2011a & SPOT 2011b \\
\hline Scene ID & 4 146-356 05-01-05 & 4 145-356 06-01-14 & 4 146-356 11-01-20 & 4 145-356 11-01-20 \\
\hline scene ID & 07:35:20 21 & 07:40:35 21 & 07:26:16 1। & $07: 26: 1721$ \\
\hline K-J identification & $146-356$ & $145-356$ & $146-356$ & $145-356$ \\
\hline Date & 5.1.2005 7:35 & 14.1.2006 7:40 & 20.1.2011 7:26 & 20.1.2011 7:26 \\
\hline Instrument & \multicolumn{4}{|c|}{ HRV IR 2} \\
\hline Shift Along Track & \multicolumn{4}{|c|}{00} \\
\hline Preprocessing level & \multicolumn{4}{|c|}{$2 A$} \\
\hline Spectral mode & \multicolumn{4}{|c|}{$X I$} \\
\hline Number of spectral bands & \multicolumn{4}{|c|}{4} \\
\hline Spectral band indicator & \multicolumn{4}{|c|}{ XS1 XS2 XS3 XS4 } \\
\hline Gain number & 5443 & 5443 & 6653 & 5543 \\
\hline Ahsolute calibration gains & XS1 2.07876 XS2 & XS1 2.04261 XS2 & XS1 3.08983 XS2 & XS1 1.91927 XS2 \\
\hline$\left(1 / W^{*} m 2 * s r^{*} \mu m\right)$ & 1.84893 XS3 2.04633 & 1.82614 XS3 2.03128 & 4.11233 XS3 2.93701 & 2.64938 XS3 2.00568 \\
\hline & XS4 8.25743 & XS4 816949 & XS4 9.05250 & XS4 8.00082 \\
\hline Orientation angle & 8.9 degree & 8.8 degree & 8.6 degree & 8.6 degree \\
\hline Incidence angle & R28.6 degree & R18.2 degree & L2.5 degree & R1.9 degree \\
\hline \multirow{2}{*}{ Sun angles (degree) } & Azimut: 128.5 & Azimut: 126.4 & Azimut: 121.8 & Azimut: 121.5 \\
\hline & Elevation: 57.0 & Elevation: 57.7 & Elevation: 55.3 & Elevation: 54.9 \\
\hline Number of lines & 3,521 & 3,436 & 3,386 & 3,385 \\
\hline Number of pixels per line & 4,433 & 3,911 & 3,612 & 3,609 \\
\hline \multicolumn{5}{|l|}{ Scene Center Location } \\
\hline Latitude & $\mathrm{S}^{\prime} 03^{\circ} 00^{\prime} 19^{\prime \prime}$ & $\mathrm{S} 00^{\circ} 00^{\prime} 18^{\prime \prime}$ & $5003^{\circ} 00^{\prime} 20^{\prime \prime}$ & $\mathrm{S}^{\prime} 03^{\circ} 00^{\prime} 17^{\prime \prime}$ \\
\hline Longitude & $\mathrm{E} 040^{\circ} 03^{\prime} 51^{\prime \prime}$ & $\mathrm{E} 039^{\circ} 34^{\prime} 22^{\prime \prime}$ & $\mathrm{E} 040^{\circ} 07^{\prime} 26^{\prime \prime}$ & $\mathrm{E} 039^{\circ} 36^{\prime} 30^{\prime \prime}$ \\
\hline Pixels number & 2,256 & 1,976 & 1,803 & 1,806 \\
\hline Line number & 1,766 & 1,720 & 1,692 & 1,692 \\
\hline
\end{tabular}

\section{Results}

\section{Land cover change}

The spectral reflectance of vegetation canopies is known to be influenced by several factors including the overall life form of the vegetation, leaf properties, vegetation height or tree size, the frac- tional cover of vegetation, soil colour and the health and water content of leaves (Belward 1991). The net effect is that the same vegetation type may have many spectral manifestations in the image (Woodcock et al. 2002). This may cause confusion between classes. The results from the land cover change analysis are visible in Figure 5. 


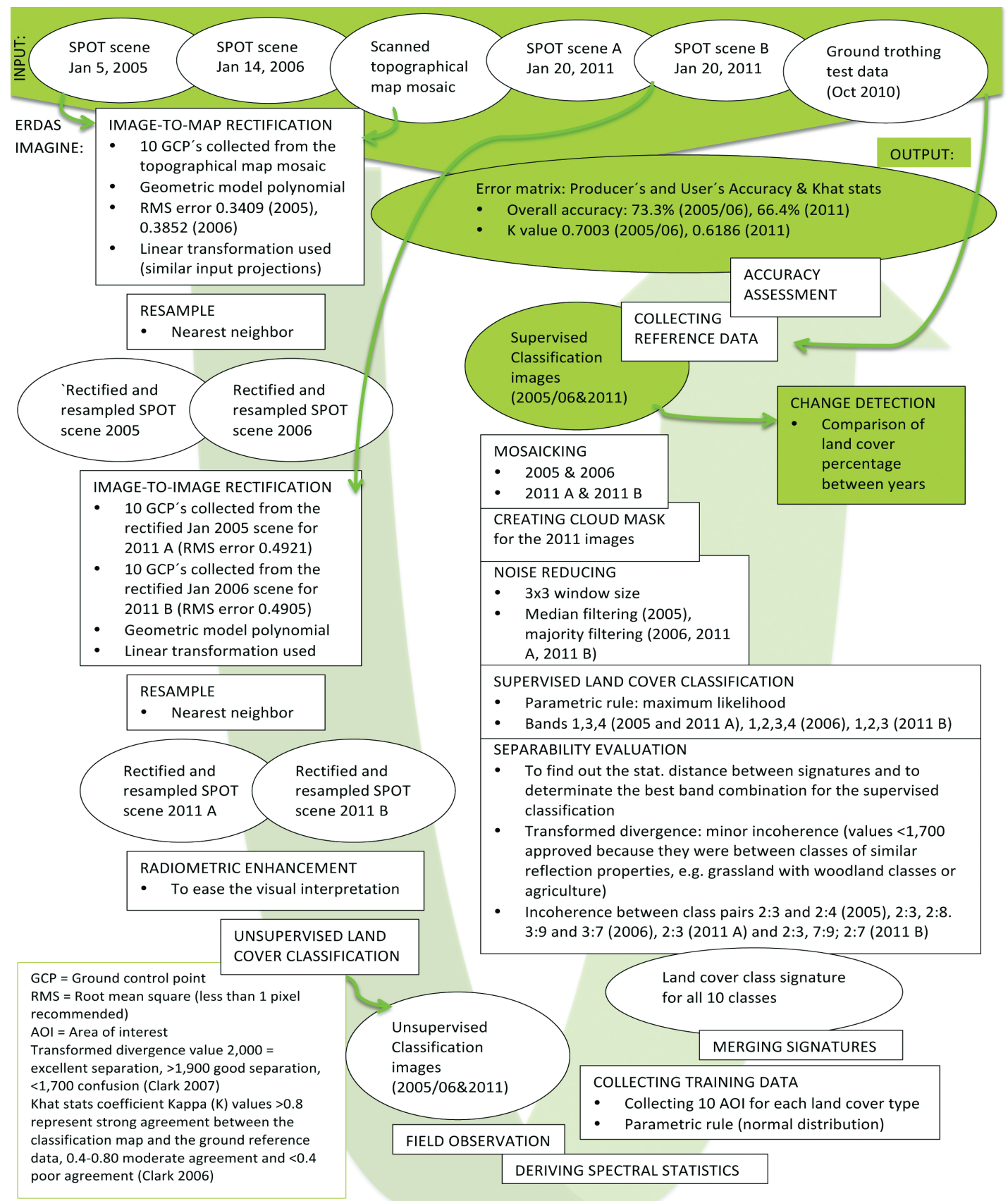

Fig. 4. Geo-processing workflows of deriving land cover classification data from satellite imagery. 
Table 4. LCCS legend describes the ten land cover classes created for Dakatcha Woodland.

\begin{tabular}{|c|c|c|c|c|}
\hline ID & User Land Cover Name & LCCS Code & $\begin{array}{l}\text { LCCS Boolean Formula } \\
\text { (Classifiers) }\end{array}$ & User Description \\
\hline 1 & Water & $7015-5$ & A1B1C2D2-A5 & Permanent water bodies. \\
\hline 2 & $\begin{array}{l}\text { Woodland closed }>65 \% \\
\text { (Brachystegia type) }\end{array}$ & 20096 & A3A10B2C1D1E1 & $\begin{array}{l}\text { Dense woodland with Brachystegia species } \\
\text { dominating. }\end{array}$ \\
\hline 3 & $\begin{array}{l}\text { Woodland open } 40-15 \% \\
\text { (Brachystegia type) }\end{array}$ & 20138-3012 & A3A11B2C1D1E1-A13 & $\begin{array}{l}\text { Sparse woodland with Brachystegia species } \\
\text { dominating. }\end{array}$ \\
\hline 4 & Woody vegetation & 20138-1 & A3A11B2C1D1E1-A12 & $\begin{array}{l}\text { Sparse to dense woodland with mixed tree } \\
\text { species. }\end{array}$ \\
\hline 5 & Thicket (Cynometra type) & $20159-12374$ & A4A10B3C1D1E1-B14 & $\begin{array}{l}\text { Dense thicket with Cynometra species } \\
\text { dominating. }\end{array}$ \\
\hline 6 & Bushland & 20180-13476 & A4A11B3C1D1E1-B9 & Mainly riverine bushland areas. \\
\hline 7 & Agriculture 1 & 11391 & A4XXXXC2D1 & $\begin{array}{l}\text { Agricultural lands with several crops (maize, } \\
\text { legumes, fruit trees, pineapples, etc.) }\end{array}$ \\
\hline 8 & Agriculture 2 & 11393 & A4XXXXC2D1D8 & Agricultural lands mainly on fallow. \\
\hline 9 & Grassland & $20209-12212$ & A6A11B4C1E5-B12 & Natural grasslands. \\
\hline 10 & Bare areas & 6001 & $\mathrm{~A} 1$ & $\begin{array}{l}\text { Bare areas, e.g. bare rock in depressions and } \\
\text { soil on the roads and town areas. }\end{array}$ \\
\hline
\end{tabular}

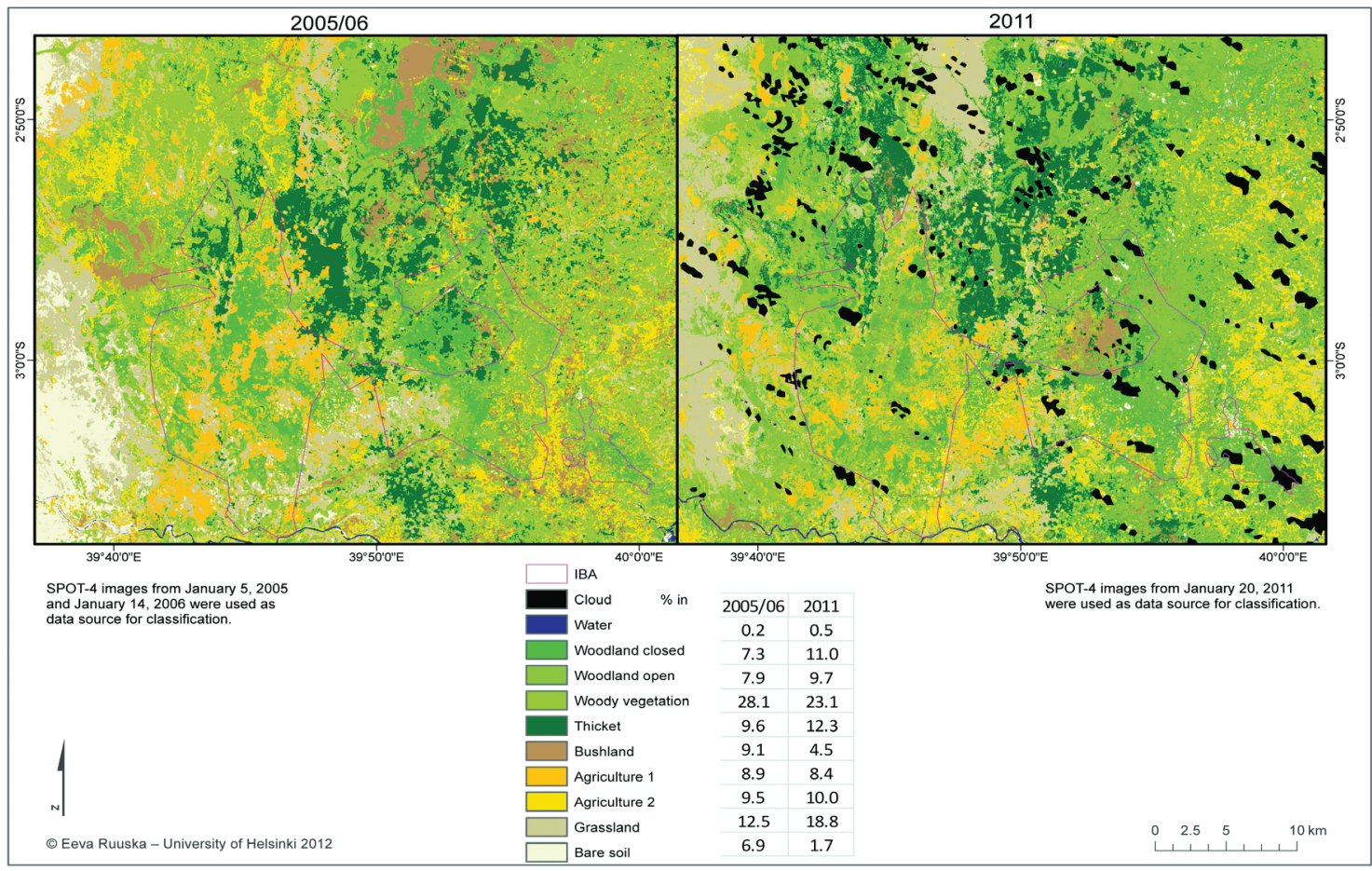

Fig. 5. Land cover in Dakatcha Woodland in 2005/06 and 2011. Land cover percentages of each land cover type for the 2005/06 and 2011 classifications in Dakatcha Woodland area. 
It is visible that the woodland areas are fragmenting, but concentrations of Brachystegia type woodland and Cynometra thicket still exist. Woodland cover has slightly increased from 2005 to 2011 from $20.7 \%$ to $25.2 \%$. However, there are significant changes in the spatial distribution of the forest areas, which no longer quite coincide with the IBA. The woodland classes have decreased especially on the western block of the IBA, giving way to agriculture and woody vegetation, which have both increased in area. Woody vegetation is classified as the biggest land cover class. However, it has varying reflection curves due to the variety of plants and canopy covers, which makes the differentiation from woodland classes difficult. Thicket class has also grown in area from $9.6 \%$ to $12.3 \%$. Some thicket areas have increased outside the western IBA block - the change is from woody vegetation, but on the other hand some woodland and thicket have given way to bush land in the inner section of the eastern block. The differentiation between grassland and bare land proved difficult because of the shallow vegetation cover and similar soil properties, which can be seen especially in the western side of the area. The reflection from the unpaved roads and other constructed areas could not be differentiated from natural bare areas.

\section{Importance of charcoal to livelihoods}

Small-scale agriculture is still the main livelihood in Dakatcha Woodland, providing more than half of the household income to nearly $60 \%$ of the assessed households. Despite the poor agricultural conditions, pineapple was still found to bring income to many households in its limited growing zone in Mulunguni, Chamari, Wakala and Dololo, although it was found that the local youth prefer working in the tourism industry in Malindi or in other jobs in Mombasa because they provide easier income.

A fair half $(50.6 \%)$ of the households is involved in charcoal production. The figure is higher than the result, $39.6 \%$, cited in a previous study (Nature Kenya 2010). It can be discussed if the closeness of the assessed households to the main charcoal production areas influenced the result. More than half of the households produced charcoal on community land and women were involved in producing $41.5 \%$ of the charcoal. Interestingly, it was found out that charcoal is produced also as a means to obtain income when unexpected expenses like medical needs appear.

Households obtain in average 41.9 head loads of firewood and 38.1 sacks of charcoal $(25 \mathrm{~kg}$ each) from the forest per month. Assessed households thus produce $51,450 \mathrm{~kg}$ of charcoal in a month. Considering that in average two to four trees of DBH $0.15-0.3 \mathrm{~m}$ are needed to produce 20 smaller sacks of charcoal, and that the average selling price of one sack is KES 100 (EUR 0.93 in Oct 2010), a couple of trees can produce KES 2,000 . Consequently, the value of one tree is KES 500 to 1,000 . Households earn in average KES 45,720 per year each from charcoal sales. Acknowledging these figures, it is easy to understand why charcoal production is common as an income-generating activity.

\section{The charcoal cycle and environmental implications}

Field observations revealed that wood extracted for charcoal production is from indigenous forests and woodlands as the households named more than 40 tree species that are used as firewood and charcoal. The most commonly named were $\mathrm{Mka}$ mi (Newtonia hildebrantii), Mrihi (Brachystegia speciformis) and Mkulu (Diospyros cornii). The used kiln type is above-ground mound kiln formed of piled wood, grass and earth, as also defined by FAO (2010b) and Kinyanjui (1987). The kilns are most often four to five meters in length, $1.2 \mathrm{~m}$ in width and 0.6 to $0.8 \mathrm{~m}$ in height. Around a kiln this size, there usually are two to four tree stumps, often cut as high as 0.5 to $0.7 \mathrm{~m}$ above ground with an axe. The diameter of the stumps from that height is in average 0.25 to $0.30 \mathrm{~m}$. The lavish use of wood for charcoal production is a sign of the lack of knowledge in efficient and sustainable production methods. The trees could be cut from their stems with proper saws and the charcoal pieces could be pulverised and pressed into pellets if the knowledge of proper techniques and the means to produce were in place. Figure 6 demonstrates the charcoal cycle in the study area.

For transporting forest products from Dakatcha Woodland, a license from the Kenya Forest Service (KFS) office in Gede is needed. A one-entry permit costs KES 1,000. Transporters having less than 5 sacks are not charged since it is regarded to be for household use. However, KFS is considering charging them too because it is known that 
bicycle transporters often take the charcoal to Malindi to be sold, and actually nearly fulfil the demand there. $60 \%$ of the charcoal produced in Dakatcha Woodland is exported to Kilifi and Mombasa, and almost all of the rest to Malindi (Ruwa 2010).

In addition to the license, in the Marafa road toll, small canters pay a cess of KES 200 - and bigger ones KES 500 - when passing by loaded. The toll is functioning day and night with a guard always present. This cess goes directly to the Marafa District Commissioner, according to local informants. There are three other tolls along the roads leading out from Dakatcha Woodland. These too are functioning night and day. According to the toll guards, on the northern road from Marafa towards Sabaki Bridge, around 50 loaded canters pass by weekly, most of them during the night. 7 to 10 loaded canters pass by weekly the southern toll point on the hillier road (personal communication on April 24, 2011). The northernmost road toll point close by Fundisa was not assessed. The majority of the cess is for administration expenses (Kinayia 2011), and only a part for promoting tree plantations in schools and other places in Dakatcha Woodland (Ruwa 2010).

All the vehicles coming from Dakatcha Woodland pass by the Sabaki Bridge, the only entrance to Malindi town from the north. According to the field observations in Sabaki Village and communication with Mumbu (2010) and Ruwa (2010), a canter can take about 100 smaller sacks at one time, while a 10-wheeler lorry may take up to 150 big sacks; a fully loaded pick up carries up to 64 sacks, a fully loaded matatu 15, and a minibus 20 sacks on the roof. Observations during one week in October 2010 in the Sabaki Bridge reveal an average of 718 sacks transported daily, totalling up to $160,700 \mathrm{~kg}$ of charcoal in a week (Fig. 7).

In towns, canters and lorries usually sell the charcoal to brokers who have negotiated prices with clients to facilitate the commerce. According to field interviews, the transporters are probably paying themselves off if any problems occur with the police. The brokers and other resellers in towns sell the bigger sack for KES 600 to 1,000 whereas the smaller sacks are sold for KES 300 to 400 , and a tin or a small plastic bag of one $\mathrm{kg}$ of charcoal for KES 20 in April 2011, according to observations in Marafa, Malindi and Mombasa. An average family of 8 persons copes with one smaller sack for about a week if charcoal is used as the only energy source for cooking (Ruwa 2010).

Out of the 80 responding households, 14 were not aware of the consequences of excessive forest resource use. The rest stated that less reliable rainfall and prolonged droughts are the most severe consequence together with increased soil erosion. A third of the households saw that the best use of Dakatcha Woodland would be conservation and another third named farming, while a quarter of the households named sustainable use of the land and forest. Poverty is the main hindrance to the best utilisation of the Dakatcha Woodland along with the lack of title deeds, according to the households. Only one of the assessed households had title deed for their land. All but one household wanted formal protection "for our own use and for the future generations". Half of the households would plant trees as a means to conserve the forest, whereas 20 households said that agroforestry could help conserving the forest. Only three households mentioned fencing the forest as a means to conserve it, showing the importance of forest resources to local livelihoods.

\section{Discussion}

FAO (2010a) has stated that land use and land cover change is often driven by population growth, which indeed is high in Dakatcha Woodland. Charcoal production and firewood extraction have contributed to the change of land cover in Dakatcha Woodland. It was suggested earlier that charcoal production has been high especially on the western block of the IBA, around Mulunguni and Dakatcha villages. The results of the GIS analysis support this information. Previous studies have suggested a decline in forest cover in Dakatcha Woodland and surrounding area. Findings in my study were actually quite the opposite - the woodland areas have slightly increased, but it was found that they are fragmenting and the spatial distribution has changed. The differences in defining the study area, land cover classes and classification process may explain the difference from previous studies. Concentrations of Brachystegia woodland and Cynometra thicket still exist, but they no longer quite coincide with the IBA in the site. The IBA area definition should be questioned due to these findings as the Brachystegia woodland is considered to be the main breeding 


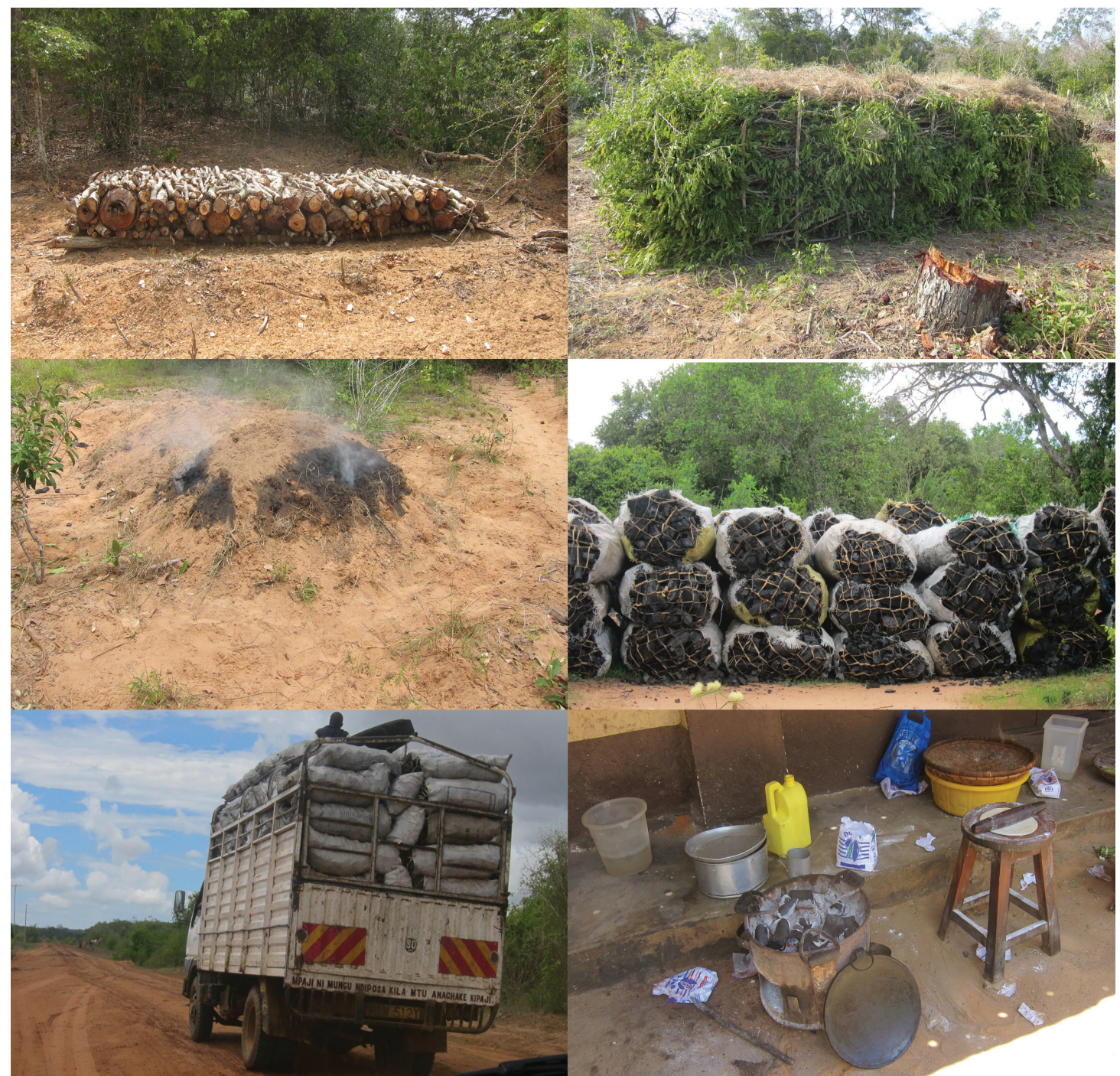

Fig. 6. Charcoal production, transportation and use in Dakatcha Woodland. In several charcoal production sites pieces of trunks were left on the ground un-burned or partially-burned, and quite an amount of smaller pieces of charcoal enough to fill up several smaller sacks could be found on the already harvested kilns. Photographs were taken in October 2010 and in April 2011 by Eeva Ruuska.

site for the endangered Clarke's Weaver (Nature Kenya 2008).

As the previous chapters suggest, the charcoal offers an important livelihood for the local households in Dakatcha Woodland, but it also degrades the forest resources, which consequently impacts the rest of the forest ecosystem services, and thus causes deterioration of livelihoods as described by the ecosys- tem services theory (MA 2005). Charcoal production in the area is and will remain high due to demand from Malindi, Kilifi and Mombasa, and due to the income it brings to local population. Generations after generations continue with lavish resource utilization due to the lack of (environmental) education, suitable legal frameworks, unclear and unjust land tenure and bad management, which was discussed 


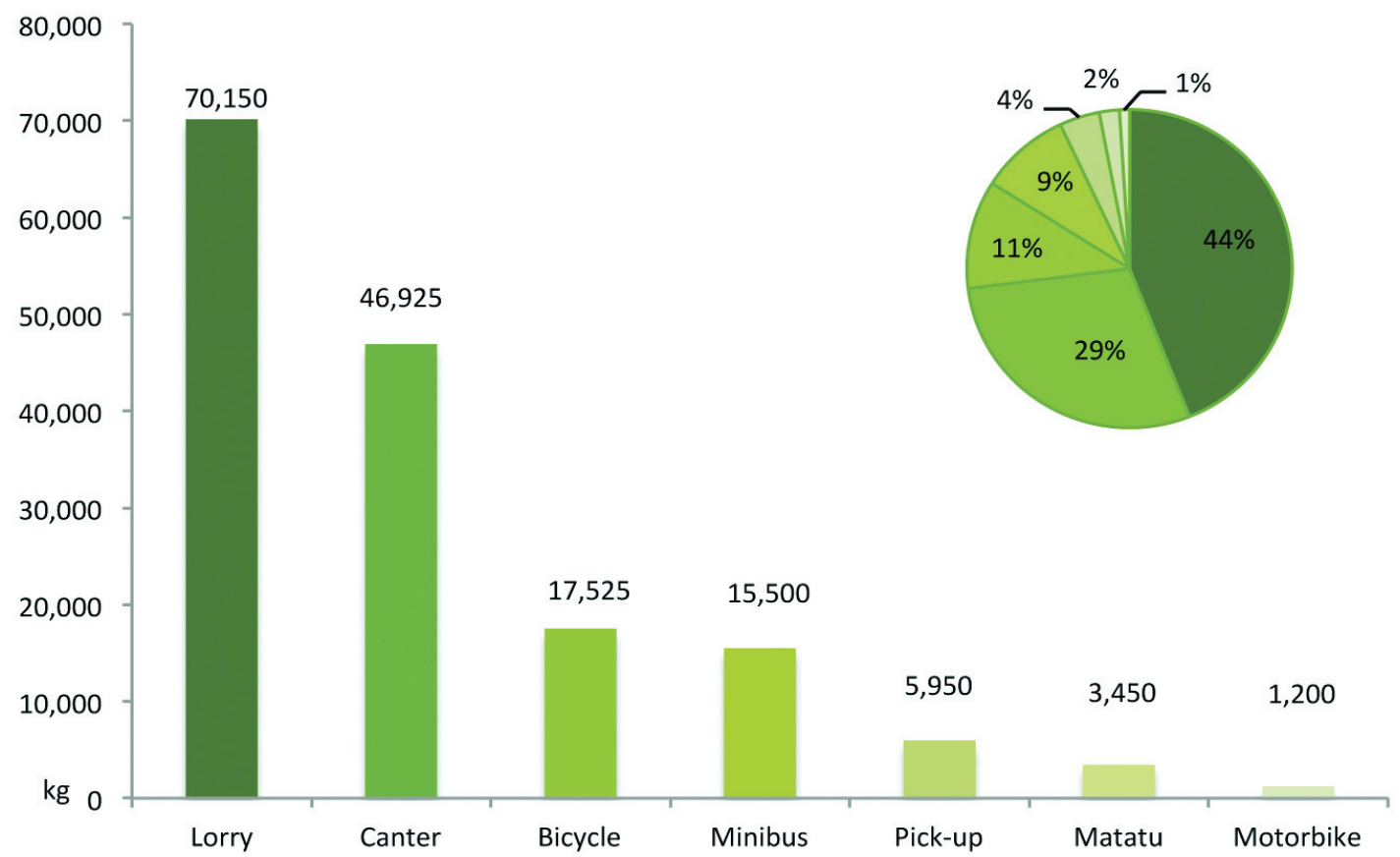

Fig. 7. Charcoal transported through the Sabaki Bridge by different means of transport in April 18th to 24th, 2011. Observations were made between $6 \mathrm{am}$ to $6 \mathrm{pm}$ hence no night trafficking is counted in the figures.

by Mbuvi et al. (2011).Livelihoods are unsustainable because people lack alternatives.

In order to maintain biodiversity and ecosystem services in the area and bring about development, the sustainability of community-based incomegenerating activities (eco-tourism, bee-keeping, etc.) needs to be developed further, sustainable models of land and forest management need to be increased, alternative sources of energy and devices that save energy must be supported, land tenure must be safeguarded for all, and the forest area must be adjudicated and zoned. In order to combat tree logging for charcoal production it is not enough to gazette the area. This means charcoal production will take place in another place and yet another place as long as there is trees left somewhere. According to Ruwa (2010), increase in agroforestry to produce charcoal from planted trees instead of indigenous forest is needed in Dakatcha Woodland. Afforestation programmes of fast growing tree species could provide alternative sources of forest goods and release pressure on the woodland. As suggested by Mbuvi et al. (2011) the management plan should be done according to the degradation levels of the forest: less disturbed as conservations areas and highly disturbed as settlement areas, which could be under farm forestry controlled by Participatory Forest Management (PFM); areas with high biodiversity could be designated as protected (no-go-zone) areas managed by the Forest Department (FD). The zoning can only be done having knowledge of the land cover.

The semi-illegal and part-time nature of charcoal production makes few charcoal-makers willing to invest in improved charcoal kilns because of the risk of punitive official measures and taxes. For this reason, dissemination of improved charcoal techniques to the informal sector has proved difficult (FAO 2010b). This gives incentive both to legalise the charcoal industry and to improve capacity building. The semi-illegality also maintains charcoal production as part of the informal economy and thus outside the tax system, which, if properly handled, benefits society as a whole 
(Hakkarainen \& Wilska 2007). The Charcoal Regulation that aims at environment-friendly and sustainable production exists but it is not respected, especially in the remote areas of the country like Dakatcha Woodland. Reasons include, among others, lack of resources for control and bribing, which Ngari (2011) opines is the case in local administration and County Council levels. All management actions require increased cooperation between local communities, NGOs and the administration. Charcoal production can be a viable livelihood strategy if forest resources are managed sustainably and if suitable settings for production are in place.

In order to lower the demand for charcoal, other means of sustainable energy provision and utilisation must be developed and subsidised. This can mean subsidies to electricity and cooking oil, education on the effects fuelwood and charcoal smoke have on health, the development of more efficient cooking methods in order to lessen the amount of charcoal used, the development of solar power cookers, etc. Increasing fuel prices set demands for other sustainable energy sources like photovoltaic energy, which has the world's highest household penetration rate in Kenya (Goldemberg 2000), although the reality in Dakatcha Woodland tells differently. Solar thermal energy is another option for space heating and cooling, water heating, crop drying and solar cooking: Integrated Food Security Program (IFSP) has created a food warmer with insulating banana leaves and cloth to which the pot is wrapped before it is put in a basket (IFSP 2004). This could be a viable idea to be disseminated also in Dakatcha Woodland. However, the lack of government seriousness related to sustainable energy discussion opposes the development (Ngari 2011). Improved stoves must meet the needs and preferences of users as a stove is not merely an appliance for heating food, but often acts as social focus, means of lighting and space heating. Some foods are also believed to taste better when cooked using firewood or charcoal instead of electricity - efficiency is thus not necessarily the first determinant when choosing the cooking device. It must be remembered that in the rural selfsufficient economy, life contains many risks and uncertainties, as the main aim of production is to safeguard one's own subsistence. This leads to avoiding risks and to approaching new inventions and experiments with caution (Todaro 1988 in Hakkarainen \& Wilska 2007).

\section{Conclusions}

The main findings of this study state that the production of charcoal is significant in the research area. It is a major source of livelihoods, and even more so due to the lack of alternatives and of interest from the government and investors to develop the area. Charcoal was found to be an important source of energy in a setting were few alternatives are available and the energy policies do not incentive a reduction in the utilisation of this resource. Charcoal production is also a source of forest degradation and ecosystem services decrease in Dakatcha Woodland.

Many themes from this paper could be elaborated further. The land cover change could be studied in a longer time span and in more detail. A postclassification comparison where the classified images are compared to each other pixel by pixel using the change detection matrix would bring more information on the spatial change in land cover classes than a mere comparison of class percentages (Jensen 1996). This paper took a holistic view to find out how charcoal production influences the changing environment and local livelihoods in Dakatcha Woodland and what could be done to increase the sustainability of the current situation, both regarding the environment and the local livelihoods.

According to the findings, it seems that the local communities are willing to preserve Dakatcha Woodland provided that they get alternative livelihoods. Half of the households would conserve the woodland by planting trees, and a mere fifth would use methods of agroforestry. These are recommended ways to start building a sustainable future for Dakatcha Woodland. Cooperation between different stakeholders is a prerequisite for the sustainable management of the area, while differing interests of different stakeholder groups should all be taken into consideration when planning the future of the woodland.

A change in sustainable land and forest management models is needed along with environmental education for both local communities and decision makers. The state of the environment needs to be monitored in order to be able to detect changes in the land cover, and the causes and consequences of these changes. All the stakeholders should understand the interrelations between biodiversity, ecosystem services and the destructive nature of human livelihoods - the realisation of the destructiveness of one's actions may be enough to start the change. In 
short, the human-nature relationship must become sustainable today in order to allow future generations to enjoy the area tomorrow.

\section{NOTES}

${ }^{1}$ This paper is a summary of a master thesis published by the author in the Ethesis service of the University of Helsinki in April 2012.

${ }^{2}$ The following people were interviewed for their expert view for the study: an officer from Marafa Government Office (2011); Dakatcha Woodland site conservation officer for Nature Kenya, Dominic Mumbu (2010); Conservation program manager for Nature Kenya, Alex Ngari (2011); Malindi district physical land use planner, Riungu Mwenda (2011); and Kenya Forest Service Malindi district officer, Kalama Ruwa (2010).

\section{ACKNOWLEDGEMENTS}

The master thesis on which this paper is based on was made possible by financial support of the Embassy of Finland in Nairobi, Nature Kenya and the University of Helsinki. I want to thank Prof. Petri Pellikka and Dr. Mika Siljander from University of Helsinki for supervision. Dr. Marion Pheifer from University of York enabled the acquisition of SPOT satellite scenes. The study would not have been realised without my driver, research assistant and friend Mr. Ken Muhia Gichera, and research assistants Mr. Thomas Kalume, Mr. Samson Katisha, Mr. Samuel Kenga, Mr. Joseph Mangi and Mr. George Odera, as well as the people of Dakatcha Woodland.

\section{REFERENCES}

Amous S 1999. The role of wood energy in Africa. Food and Agriculture Organization. <http://www. fao.org/docrep/x2740e/x2740e02.htm> 28.3.2011.

Anderson T, Doig A, Rees D \& S Khennas 1999. Rural energy services. A handbook for sustainable energy development. IT Publications, London.

A Rocha Kenya 2009. Report on Dakatcha Woodland survey. Unpublished report. A Rocha Kenya, Watamu, Kenya.

Belward AS 1991. Spectral characteristics of vegetation, soil and water in the visible, near-infrared and middle-infrared wavelengths. In Belward AS \& Valenzuela CR (eds). Remote sensing and geographical information systems for re- sources management in developing countries, 31-53. Kluwer Academic Publishers, Dordrecht. Bila AD \& Lindgren D 1998. Fertility variation in Milletia Stuhlmannii, Brachystegia Spiciformis, Brachystegia Bohemii and Leucaena Leucocephala and its effects on relatedness in seeds. Forest Genetics 5: 2, 119-129.

Braun HMH 1980. Agro-Climatic Zone map of Kenya. Appendix 2 to Report no. E1. Republic of Kenya, Ministry of Agriculture Kenya Soil Survey, Nairobi.<http://eusoils.jrc.ec.europa.eu/esdb_archive/eudasm/africa/maps/afr_keacz2.htm> 7.3.2011.

Chambers R \& Conway G 1991. Sustainable rural livelihoods: practical concepts for the 21 st century. IDS Discussion Paper 296.

CIFOR 2005. Forests and Africa's development: $\mathrm{Cl}$ FOR in Sub-Saharan Africa. Centre for International Forest Resources, Bogor, Indonesia. < http://www.cifor.cgiar.org/publications/pdf_files/ brochures/BCIFOR0501.pdf> 4.4.2011.

Clark BJF 2006. TAITA Project - GIS applications in environmental monitoring in the Taita Hills. Course material. Department of Geography, University of Helsinki.

Clark BJF 2007. 56282e: Environmental monitoring and modelling using remote sensing and GIS. Remote sensing practical 3: Deriving a land cover model for the Taita Hills. Course material. Department of Geography, University of Helsinki.

Diaz-Chavez R, Mutimba S, Watson H, RodriguezSanchez S \& Nguer M 2010. Mapping food and bioenergy in Africa. Forum for Agricultural Research in Africa, Ghana.

Eliasch J 2008. Climate change: financing global forests: the Eliasch review. Earthscan, London.

FAO 2006. Better forestry, less poverty. A practioner's guide. FAO Forestry Paper 149. Food and Agriculture Organization of the United Nations, Rome.

FAO 2010a. What woodfuels can do to mitigate climate change? FAO Forestry Paper 162. Food and Agriculture Organization of the United Nations, Rome.

FAO 2010b. Criteria and indicators for sustainable woodfuels. FAO Forestry Paper 160. IEA Bioenergy, Food and Agriculture Organization, Rome.

Foeken D 2003. Physical resources and infrastructure. In Hoorweg J, Foeken D \& Obudho RA (eds). Kenya coast handbook: culture, resources and development in the East African Littoral, 29-42. LIT Verlag, Hamburg.

FORESTRY 2011. DBH. <http://forestry.about.com/ cs/glossary/g/dbh.htm>. 1.8.2011.

Goldemberg J (ed) 2000. Energy and the challenge of sustainability. World Energy Assessment, United Nations Development Program, United Nations Department of Economic and Social Affairs, World Energy Council, New York.

Hakkarainen O \& Wilska K 2007. Locating impoverishment. Report Series 87. Kehitysyhteistyön Palvelukeskus (KEPA), Helsinki. 
Hirsjärvi S, Remes P \& Sajavaara P 2004. Tutki ja kirjoita. $10^{\text {th }}$ ed. Kustannusosakeyhtiö Tammi, Helsinki.

Hirsjärvi S \& Hurme H 2006. Tutkimushaastattelu Teemahaastattelun teoria ja käytäntö. $4^{\text {th }}$ ed. Helsinki University Press, Helsinki.

IFSP 2004. Food warmer guide. Integrated Food Security Programme, Mulanje, Malawi. <www.fuelnetwork. org/index.php? option $=$ com_docman\&task=doc...>. 3.6.2011.

Ikiara G K 2003. Employment. In Hoorweg J, Foeken D \& Obudho RA (eds). Kenya coast handbook: culture, resources and development in the East African littoral, 237-246. LIT Verlag, Hamburg.

ISRIC 2010. SOTER database of Kenya (Version 2.0). ISRIC - World Soil Information, Vageningen. <http://www.isric.org/UK/About+ISR/C/Projects/ Track+Record/SOTER+Kenia.htm > 5.1.2011.

Jensen JR 1996. Introductory digital image processing. A Remote Sensing perspective. Prentice Hall, New Jersey.

Kenya Topographical Map 1:50,000; sheet mosaic 1981/1991. 186-1 Dakawachu (1981), 186-2 Mukale (1981), 186-3 Dakabuko (1981), 186-4 Hadu (1981); 187-1 Kurawa (1981), 187-3 Fundisa (1981); 192-1 Matolani (1991), 192-2 Jilore (1991) Survey of Kenya.

Kinayia G 2011. Personal communication with Malindi County Council clerk on April 28, 2011. Malindi County Council, Malindi.

Kinyanjui M 1987. Fueling Nairobi: the importance of small-scale charcoaling enterprises. Unasylva 39: 4, 17-28.

KNBS 2007. Kenya integrated household budget survey - 2005/06 (revised ed). Kenya National Bureau of Statistics (KNBS). Ministry of Planning and National Development, Nairobi, Kenya.

KNCHR 2006. The Malindi inquiry report 2006. Report of a public inquiry into allegations to human rights violations in Magarini, Malindi. Kenya National Commission on Human Rights, Nairobi.

MA 2005. Ecosystems and human well-being: biodiversity synthesis. Millenium Ecosystem Assessment. World Resources Institute, Washington, DC.

Macharia PN 1996. Vegetation of Malindi area. Miscellaneous Report No. M51. Kenya Agricultural Research Institute, National Agricultural Research Laboratories, and Kenya Soil Survey, Nairobi.

Marafa Government Office 2011. Personal communication with an anonym government officer on April 24, 2011. Marafa, Kenya.

Mbuvi MTE, Nahama ET \& Musyoki JK 2011. Master plan for Dakatcha Woodland area: an Important Bird Area (2011-2035). Draft. Nature Kenya. Marafa, Kenya.

Muchiri MS, Gachathi F, Mairula O, Oeba V \& Mumbu D 2010. Forest inventory survey, species composition and structure description of Dakatcha Woodland. Unpublished document. Kenya Forestry Research Institute (KEFRI) \& Nature Kenya, Marafa, Kenya.
Mumbu D 2010. Personal communication with Dakatcha Woodland site conservation officer for $\mathrm{Na}$ ture Kenya on October 6, 2010. Nature Kenya, Marafa, Kenya.

Musila S, Ngari A, Jackson C, Jackson R \& Ngala D 2006. Instituting a biodiversity monitoring system of globally threatened species in Dakatcha Woodland baseline survey report. Department of Ornithology, Nature Kenya, Arocha Kenya, Forest Department, Nairobi, Kenya.

Mwambire J \& Katana G 2010. Feasibility study report on identification and information about eco-tourism sites in Dakatcha Woodland for 7th-13th June, 2010. Unpublished report. Nature Kenya, Marafa, Kenya.

Mwanikah M 2008. Land use dynamics and impacts on conservation status of Warburgia Stuhlmannii in Dakatcha and Marafa forests in Malindi district. Moi University, Graduate School of Environmental Studies. MSc thesis. Nairobi, Kenya.

Mwenda R 2011. Personal communication with Malindi district physical land use planner on April 30, 2011. District Physical Land Use Planner Office, Malindi, Kenya.

Nature Kenya 2008. Conservation for sustainable living. Investing in capacity building, nature-based enterprises and business support to conserve the Dakacha Woodland by and for local communities. Unpublished document. Nature Kenya, Nairobi, Kenya.

Nature Kenya 2010. Dakatcha socio-economic survey. Unpublished excel data sheet. Nature Kenya, Marafa, Kenya.

Ngari A 2011. Personal communication with conservation program manager for Nature Kenya on April 15, 2011. Nature Kenya, Nairobi, Kenya.

Republic of Kenya 2005. Economic survey 2005. Central Bureau of Statistics, Nairobi, Kenya.

Ruwa K 2010. Personal communication with Kenya Forest Service Malindi district office on October 13, 2010. KFS District Office, Gede, Kenya.

Skidmore A (ed) 2002. Environmental modelling with GIS and remote sensing. Taylor \& Francis, London.

SPOT 2005. Satellite image: SPOT-4 146-356 05-01-05. EOLISA - ESA (European Space Agency). <http:// earth.esa.int/EOLi/EOLi.html> 3.8.2010.

SPOT 2006. Satellite image: SPOT-4 145-356 06-01-14. EOLISA - ESA (European Space Agency). <http:// earth.esa.int/EOLi/EOLi.html> 3.8.2010.

SPOT 2011a. Satellite image: SPOT-4 146-356 11-0120. EOLISA - ESA (European Space Agency). <http:// earth.esa.int/EOLi/EOLi.html> 29.4.2011.

SPOT 2011b. Satellite image: SPOT-4 145-356 11-0120. EOLISA - ESA (European Space Agency). <http:// earth.esa.int/EOLi/EOLi.html> 29.4.2011.

Teel W 1988. A pocket directory of trees and seeds in Kenya. KENGO, Nairobi, Kenya.

Todaro MP 1988. El desarrollo económico del Tercer mundo. Alianza Editorial, Madrid.

Vagen TG 2010. Africa soil information service: hydrologically corrected / adjusted SRTM DEM (AfrHySRTM). Nairobi, Kenya and Palisades, NY: International Center for Tropical Agriculture - Tropical Soil Biol- 
ogy and Fertility Institute (CIAT-TSBF), World Agroforestry Centre (ICRAF), Center for International Earth Science Information Network (CIESIN), Columbia University. <http://www.africasoils.net/category/ tags/digital-elevation-model> 29.12.2010.

Waaijenberg H 2003. Agriculture. In Hoorweg J, Foeken D \& Obudho RA (eds). Kenya coast handbook: culture, resources and development in the East African littoral, 175-195. LIT Verlag, Hamburg.

WCED/UN 1987. Our Common Future. Published as annex to general assembly document A/42/427, Development and International Co-operation: Environment 374.
White P \& Mustalahti I 2005. Finnish forestry assistance: success story of failure? Analyses of case studies from Sub-Saharan Africa and their possible impacts on poverty reduction. Silva Carelica 48. University of Joensuu. Joensuun yliopistopaino, Joensuu.

Woodcock CE, Macomber SA \& Kumar L 2002. Vegetation mapping and monitoring. In Skidmore A (ed). Environmental modelling with GIS and Remote Sensing, 97-120. Taylor \& Francis, London. 